\title{
The Mediating Role of Conflict Management Styles Between Organizational Justice and Affective Commitment Among Academic Staffs in Malaysian Public Universities
}

\author{
Muhammad Asyraf Mohd Kassim ${ }^{1}$, Muhammad Safizal Abdullah', and Mohd Fitri Mansor ${ }^{1}$

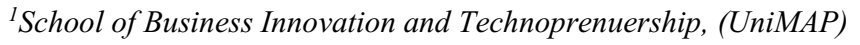

\begin{abstract}
This study analyzes in deep the effects of two major dimensions in organizational justice such as procedural and distributive justice on affective commitment through three conflict management styles such as integrating, compromising, and avoiding styles. These relationships are analyzed in advance on the extent of academic staff in Malaysian Public Universities. Partial Least Squares of Structural equation modelling (SEM) and Statistical Package Social Science (SPSS) are utilized to determine the effect of the two variables and the mediating effect of the conflict management styles. The results exhibit that procedural and distributive justice is significantly related with integrating, and compromising styles while not significantly related to avoiding style. It also revealed that integrating and compromising styles were significant with affective commitment while avoiding style does not relate with affective commitment. In conclusion, the results also showed only integrating and compromising styles mediate the relationship between procedural and distributive justice and affective commitment.
\end{abstract}

Keywords: Organizational Justice, Affective Commitment, Conflict Management Styles, Structural Equation Modelling

\section{Introduction}

Rapid developments in Malaysian Higher Education (MHE) proved that this sector is decisive in transforming Malaysia to become high income nation by the year 2020. Academic staffs in public and private higher education institutions in Malaysia mostly are involved in teaching and research and also providing professional consultancy to people for high-level job requirements in industry as this significantly contributes to the development of social economics especially in human capital development (Choong, Keh, Tan \& Tan, 2013). Therefore, academic staffs play an important role in sustaining the quality of education as they served as the backbone of any success achievements in higher education institutions.

Unfortunately, recently, MHE sector is facing with increasing turnover rate among the academic staffs as this is one of the critical issues in public and private universities in Malaysia. Choong et al. (2013) indicated that the rising turnover rate among academic staffs in universities will result to increasing recruiting cost, decreasing service quality, waste of management efforts and demoralized of other employees. Aizat, Nizam, Zaifudin and Turiman (2014) discovered that one of the factors influencing the academic staffs in Malaysian public universities leaving their organization is because lacking of affective commitment towards the organization. Academic staffs tend to leave their organization when they feel that they are not committed towards the organization (Alzahrani, 2013). Therefore, it is hard to ignore the issue of turnover among academic staffs' public universities in Malaysia.

The issue high turnover among academic staffs in Malaysian public universities has been identified as a major problem for the organizations' as it affects the organizations' performance and goals. Bahramzadeh \& Yadegari, (2010) discovered that one of the critical factors that influence high turnover is lacking of affective commitment among the staffs which is resulted from procedural and distributive justice. Employee's perception on distributive and procedural justices can significantly affect the attitudes, behavior and performance of employees working in any organizations including academic sector (Seyed, Faraahi and Taheri, 2009).

Conversely, Alzahrani (2013) revealed that conflict management styles also impacts affective commitment. Rahim (2002) revealed that applying the dual concern model of five conflict management styles on affective commitment, the conflict management styles of avoiding and dominating is negatively associated with affective commitment, but is positively associated with compromising, obliging and integrating.

Previous researches about distributive justice, procedural justice and conflict management styles have been focusing on investigating the relationship of both justices and conflict management styles on

\footnotetext{
Corresponding author: muhammadasyraf@unimap.edu.my
} 
organizational commitment each of the variables individually and separately (Tatum \& Eberlin, 2008). Hence, this has led the present study to integrate these variables in a single research framework which, will be focusing on the significance of distributive and procedural justice, conflict management styles and affective commitment among academic staffs. This study is embarked in an effort to bridge the gap in the study of affective commitment by integrating both distributive and procedural justice together with conflict management styles as the mediator. Specifically, the present study will examine the relationships between distributive and procedural justice and three dimensions of conflict management styles namely integrating, compromising and avoiding. In addition, this study also will examine the relationship between these three conflict management styles and affective commitment and the mediating role of conflict management styles between distributive justice, procedural justice and affective commitment.

\subsection{Problem Statement}

Affective commitment studies among academic staffs in Malaysia are very rare as not many researchers have studied the phenomenon in the higher education sector in Malaysia. The severity of the high turnover rate in Malaysia's higher education sector is becoming worst each year and this problem has been linked to the issue of affective commitment among the academic staffs. This was evidenced from a statistics showing the average turnover rate among academic staffs is increasing yearly. The turnover rate in MHE sector was about 30\% in year 2015 as it increase about 7\% from year 2014 (Sofiah, Zabid \& Lionel, 2016). A study conducted by Azman, Amy, Elizabeth, Kong and Ju (2015) demonstrated that the high turnover trend is mostly happen among the academic staffs where they perceived they are treated unfairly by their organization in terms of payment and workload. Thus proving that there is a dire need to examine the effects of organizational justice and conflict management styles on organizational commitment as an effective method to reduce or prevent the increasing turnover rate.

\section{Literature Review}

\subsection{Affective Commitment}

Meyer, Allen and Smith (1993) defined affective commitment as positive feelings of identification with, attachment to and involvement in the work organization. Seto (2013) indicated those employees that have higher level of affective commitment towards their organization, the more effort they will exert in performing daily tasks. Additionally, the issue of affective commitment has received attention for the past several years as organizations look for management tools and methods to enhance their employees' involvement to boost their commitment and indirectly improving organizational performance.

Zayas-Ortiz, Rosario, Marquez, and Gruneiro (2015) discovered that it is difficult for the organizations to inculcate high affective commitment among their employees as it has been established to be a significant predictor of performance and once the organisational objectives has been fulfilled, this will indicate that the affective commitment has been fully optimised by the employees. For instance, employees who recognize justice through the distribution of tasks and work processes are more likely to develop a high degree of affective commitment. Therefore, affective commitment among academic staffs is very important in order to boost their satisfaction so that they will stay with their organization.

\subsection{Distributive Justice}

Greenberg and Baron (2003) defined distributive justice as employees' perceptions of fairness in the distribution of resources between people. Elamin (2012) indicated that in determining fairness, employees will compare the value of their work inputs such as hard work, commitment and passion to the outcomes or rewards received from their organizations. The outcomes or rewards gained are in terms of increase in salary, promotions and recognition. If the employees believe the outcomes of a decision is unfair, they may engage in a conflict with their organization. Conflicts occur because of perception of injustice by employees lead to dissatisfaction, poor performance, higher absenteeism and turnover intention. Kahn and Rashid (2012) proposed that how employees' perceive they are treated in the organization can influence the work behavior and productivity of the employees.

\subsection{Procedural Justice}

Procedural justice refers to the perceived fairness present in decision making process with regard to the distribution of rewards (Lemons \& Jones, 2001). Procedural justice is a major focus of study in the field of organizational behaviour due to its impact on organizations. Colquitt (2001) indicated that distributive justice and procedural justice are moderately to highly correlated. However, distributive justice is more strongly correlated with reactions with regard to specific outcomes such as job satisfaction, whereas procedural justice is strongly related to attitudes with regard to the organizational system, institution, or authorities 
perceived to be responsible for the process and procedural decision (Tyler \& Lind, 1992).

\subsection{Conflict Management Styles}

A conflict management styles model was developed by Rahim (2002) which consisted of two dimensions namely intended for self and concern for each other with each axis measured as high and low. The first dimension clarifies the level to which an individual pursues to fulfil his needs and the second one expresses one's concern about the needs of others (Rahim, 2002). Integrating, compromising and avoiding styles are some of the conflict management styles in Rahim's model.

Integrating style is considered as one the more effective problem solving approach. The resolution of conflict requires openness, information sharing and a clear expression of the problem among the parties involved in the conflict (Rahim, 2010). Meanwhile, compromising style is generally characterized as dividing resources in some equitable fashion without resorting to alternative solutions that may seemed unfair to each party's interests. On the other hand, avoiders normally ignore the problem and do not even make the effort to resolve the conflict at all.

\section{Hypotheses}

\subsection{Relationship Between Distributive, Procedural Justice And Conflict Management Styles}

Tatum \& Eberlin (2008) presented two circumstances to demonstrate the influence of organizational justice and conflict management styles in an organizational setting. First scenario depicts the operation of high levels of justice (both distributive and procedural) within a potentially high conflict situation. The other scenario portrays low levels of justice within a potentially high conflict situation. Table 1 illustrates how sensitivity to organizational justice issues affects different uses of conflict styles when employees are embroiled in a conflict.

An employee, who is highly perceptive to justice related issues, does not steer clear from conflicts by avoiding himself unnecessarily during the resolution. Additionally, the most effective approach to addressing conflict for highly-sensitive employees is integrating and compromising styles. These conflict resolution methods afford the employees to reach an outcome that encourages information sharing, employee involvement, and a genuine demonstration of care and concern for each other.
Table 1. High and low justice and the relationship to conflict styles

\begin{tabular}{|c|c|c|c|}
\hline Scenario & $\begin{array}{l}\text { Avoiding } \\
\text { (Style 1) }\end{array}$ & $\begin{array}{l}\text { Compromising } \\
\text { (Style 2) }\end{array}$ & $\begin{array}{l}\text { Integrating } \\
\text { (Style 3) }\end{array}$ \\
\hline $\begin{array}{l}\text { Employee } \\
\text { is sensitive } \\
\text { to } \\
\text { distributive } \\
\text { and } \\
\text { procedural } \\
\text { justice } \\
\text { issues } \\
\text { (High } \\
\text { justice) }\end{array}$ & $\begin{array}{l}\text { The } \\
\text { employee } \\
\text { does not } \\
\text { avoid } \\
\text { conflict } \\
\text { because } \\
\text { the } \\
\text { employee } \\
\text { would not } \\
\text { be brought } \\
\text { into the } \\
\text { process and } \\
\text { would not } \\
\text { have access } \\
\text { to } \\
\text { information }\end{array}$ & $\begin{array}{l}\text { The employee's } \\
\text { willingness to } \\
\text { compromise, } \\
\text { however, would } \\
\text { depend on what } \\
\text { is best for both } \\
\text { the employee } \\
\text { and the } \\
\text { organization as a } \\
\text { whole }\end{array}$ & $\begin{array}{l}\text { Collaboration } \\
\text { (integration) } \\
\text { promotes } \\
\text { information } \\
\text { sharing, } \\
\text { involvement, } \\
\text { fairness in the } \\
\text { distribution of } \\
\text { outcomes, and } \\
\text { an expression } \\
\text { of } \\
\text { caring and } \\
\text { concern }\end{array}$ \\
\hline $\begin{array}{l}\text { Employee } \\
\text { is } \\
\text { insensitive } \\
\text { to } \\
\text { distributive } \\
\text { and } \\
\text { procedural } \\
\text { justice } \\
\text { issues (Low } \\
\text { justice) }\end{array}$ & $\begin{array}{l}\text { An } \\
\text { employee } \\
\text { who does } \\
\text { not care } \\
\text { about } \\
\text { fairness, } \\
\text { openness, } \\
\text { or trust } \\
\text { may opt for } \\
\text { avoiding } \\
\text { conflict and } \\
\text { thereby } \\
\text { saving time } \\
\text { and effort }\end{array}$ & $\begin{array}{l}\text { If sharing } \\
\text { information and } \\
\text { trying to reach a } \\
\text { compromise are } \\
\text { viewed as the } \\
\text { most direct way } \\
\text { to complete the } \\
\text { task, then the } \\
\text { employee may } \\
\text { adopt this style }\end{array}$ & $\begin{array}{l}\text { Employee may } \\
\text { select this } \\
\text { approach, but } \\
\text { not because of } \\
\text { justice. The } \\
\text { employee may } \\
\text { adopt } \\
\text { collaboration } \\
\text { as the best way } \\
\text { to complete the } \\
\text { review with } \\
\text { minimal } \\
\text { employee } \\
\text { resistance }\end{array}$ \\
\hline
\end{tabular}

Note. Source: Tatum and Eberlin (2008)

In contrast, employees who are less perceptive with regard to organisational justice tend to be more concerned with established procedure rather than the fairness or openness of processes (see Table 1). An employee who ignores matters relating to organisational justice is more likely to avoid conflict altogether to save time and effort. Oddly, the employee for whom organizational justice is of little concern might actually adopt the conflict resolution approach of integration. In this case, the employee's purpose is not to establish fairness in the exchange; but rather, he or she was attempting to conclude the resolution process with as little resistance as possible. Therefore, the hypotheses formulated will be:

H1: There is a significant relationship between organizational justice and conflict management styles

\subsection{Relationship Between Conflict Management Styles And Affective Commitment}

Ahmad \& Marinah (2013) stated that integrating style in conflict management plays a key role in the formation of developing affective commitment toward the organization. Employees that utilise this style confront conflicts directly and try to find new and creative solutions to the problems by balancing 
between their own needs as well as that of the others.

In contrast, Griffin and Steen (2011) in a research on secondary schools found that the conflict management style of compromising attributed to principals were positively associated with secondary level teachers' affective commitment. Conversely, the management style of withdrawing of the principals was related to lower levels of teachers' commitment.

London and Howat (1978) found that the conflict management styles of avoiding were negatively associated with affective commitment, but compromising and integrating styles were positively related to affective commitment. Therefore, it appears that those conflict management styles which allow a subordinate's opinions to be expressed and utilised as part of decision-making process in the achievement of organizational goals are the ones which will be the more fruitful in producing employees' affective commitment. In sum, the hypotheses formulated are:

\section{H2: There is a significant relationship between conflict management styles and affective commitment}

\subsection{Mediating Effect of Conflict Management Styles}

Distributive and procedural justice has been found to be positively related to affective commitment (Suliman \& Kathairi, 2013). Employees who perceive distributive and procedural justice to be high are more competent in negotiation and problem solving. The effectiveness of conflict management is the first step in enhancing employees' affective commitment towards their organization. Additionally, employees with higher levels of distributive and procedural justice have a better understanding of each other as they will work at resolving issues together without resorting to negative behaviour. For example, when faced with conflict in the workplace, these types of employees have the abilities to think positively and behave accordingly to pacify the conflicting parties (Ahmad \& Marinah, 2013). Effective and appropriate conflict management behaviours in turn are likely to improve employees' perception of justice and affective commitment in their organization. Furthermore, employees with high distributive and procedural justice tend to share their ideas with others, obtain suggestions and help from colleagues and know how to maintain a long-term and cooperative relationship with their co-workers, which will result in enhancing affective commitment towards their organization (Ndubisi, 2011). Finally, employees that are high in both justices know how to express their own ideas appropriately even if there are conflicting opinions and are able to make their detractive novel ideas more agreeable. Therefore, the following hypotheses are developed:

\section{H3: Conflict management styles mediate between distributive and procedural justice and affective commitment.}

\section{Method}

Self-administered questionnaires were developed and distributed to academic staffs in public universities in Malaysia. Respondents were academic staff from public universities located at Perlis, Kedah, and Penang. The questionnaires were distributed using a simple random sampling method. In total, 1200 questionnaires containing justiceoriented assessments, conflict management styles scales and affective commitment-related scales were distributed by hand to the respective academic staffs. Due to response rate of $25 \%$ in public universities, 1200 questionnaires were distributed in order to obtain a sample size of 300 academic staffs. The scales were measured using a five-point Likert scale ranging from (1) "strongly disagree" to (5) "strongly agree". 330 questionnaires were returned and the overall response was 27.5 per cent. From the 330 responses, 303 were usable for analyses, representing an effective rate of 25.2 per cent. Descriptive statistics of the final sample are shown in Table 2. These variables (gender, race, educational background, and working length) are considered as control variables in the following analysis.

Table 2. Descriptive statistics of sample

\begin{tabular}{|c|c|c|}
\hline Profile & Description & Frequency \\
\hline \multirow{4}{*}{ Age } & $21-29$ & 58 \\
\hline & $30-39$ & 104 \\
\hline & $40-49$ & 94 \\
\hline & $>50$ years & 47 \\
\hline \multirow[b]{2}{*}{ Gender } & Male & 112 \\
\hline & Female & 191 \\
\hline \multirow{4}{*}{$\begin{array}{l}\text { Length of Service in } \\
\text { Current University }\end{array}$} & $0-10$ & 132 \\
\hline & $11-20$ & 94 \\
\hline & $21-30$ & 61 \\
\hline & $>30$ years & 16 \\
\hline \multirow{4}{*}{$\begin{array}{l}\text { Length of Service in } \\
\text { Academic Profession }\end{array}$} & $0-10$ & 122 \\
\hline & $11-20$ & 95 \\
\hline & $21-30$ & 68 \\
\hline & $>30$ years & 18 \\
\hline \multirow{2}{*}{$\begin{array}{ll}\text { Highest } & \text { Academic } \\
\text { Qualification } & \end{array}$} & Masters & 129 \\
\hline & $\mathrm{PhD}$ & 174 \\
\hline
\end{tabular}

PLS-SEM were used to assess the goodness of measures and to test the hypotheses for this study. The mediation was tested using the bootstrapping approach as suggested by Preacher and Hayes (2008). 


\subsection{Measures}

Distributive justice (four items) and procedural justice (seven items) were assessed based on the measures developed by Rahim, Magner and Shapiro (2000). The Cronbach's alphas were both 0.93 for distributive justice and procedural justice. The scale was measured using a five-point Likert scale ranging from (1) "strongly disagree" to (5) "strongly agree".

The Rahim Organizational Conflict Inventory (ROCI-II) Form B (Rahim, 1983) was used in this study to measure the three styles of managing interpersonal conflict, consisting of 16 items which include integrating (seven items), compromising (four items), and avoiding (five items). The items were modified to measure subordinates' perception of their managers' styles in handling disagreements with them. Employees were instructed to indicate the extent of fairness to which they perceive the way their manager handled interpersonal conflicts within the organisation on a five- point Likert type scale, ranging from strongly disagree (1) to strongly agree (5). The reliability coefficients for integrating, compromising and avoiding styles were 0.89, 0.86, and 0.73 respectively. Affective commitment was measured based on the scales developed by Meyer, Allen, and Smith (1993) containing six items. The Cronbach's alpha for the scale is 0.82 . The measures were measured using a five-point Likert scale ranging from (1) "strongly disagree" to (5) "strongly agree".

\section{Findings}

\subsection{Goodness of Measures}

The goodness of measures for the variables in the study was assessed using construct validity, convergent validity, discriminant validity, and reliability analysis. For the purpose of construct validity, Hair et al. (2013) indicated that every loading that are greater than 0.50 on a particular construct are considered significant. Therefore, loadings below 0.50 were removed and there were no reported cross loadings. As a result, the constructs were valid for this study. Table 3 shows the factor loadings for each construct.

Table 3. Loadings and cross loadings

\begin{tabular}{|l|l|l|l|l|l|l|}
\hline & AC & AV & CO & DJ & IN & PJ \\
\hline AC1 & 0.8 & & & & & \\
\hline AC3 & 0.8 & & & & & \\
\hline AC4 & 0.9 & & & & & \\
\hline AC5 & 0.8 & & & & & \\
\hline AC6 & 0.8 & & & & & \\
\hline AV1 & & 0.6 & & & & \\
\hline AV2 & & 0.6 & & & & \\
\hline AV3 & & 0.6 & & & & \\
\hline AV4 & & 0.5 & & & & \\
\hline AV5 & & 0.6 & & & & \\
\hline CO1 & & & 0.7 & & & \\
\hline CO2 & & & 0.6 & & & \\
\hline
\end{tabular}

\begin{tabular}{|l|l|l|l|l|l|l|}
\hline CO3 & & & 0.8 & & & \\
\hline CO4 & & & 0.7 & & & \\
\hline DJ1 & & & & 0.7 & & \\
\hline DJ2 & & & & 0.9 & & \\
\hline DJ3 & & & & 0.7 & & \\
\hline DJ4 & & & & 0.9 & & \\
\hline IN1 & & & & & 0.8 & \\
\hline IN2 & & & & & 0.7 & \\
\hline IN3 & & & & & 0.8 & \\
\hline IN4 & & & & & 0.8 & \\
\hline IN5 & & & & & 0.9 & \\
\hline IN6 & & & & & 0.8 & \\
\hline IN7 & & & & & 0.9 & \\
\hline PJ1 & & & & & & 0.7 \\
\hline PJ2 & & & & & & 0.7 \\
\hline PJ3 & & & & & & 0.8 \\
\hline PJ4 & & & & & & 0.8 \\
\hline PJ5 & & & & & & 0.8 \\
\hline PJ6 & & & & & & 0.7 \\
\hline
\end{tabular}

Next, to determine the convergent validity, factor loadings, composite reliability (CR), and average variance extracted (AVE) were analysed. Table 4 exhibits that all factor loadings are above 0.50 , the composite reliabilities are above 0.70 , and the AVEs are above 0.50 . Thus, the convergent validity of the constructs was accepted.

Table 4. Results of measurement model

\begin{tabular}{|c|c|c|c|c|}
\hline $\begin{array}{l}\text { Model } \\
\text { Construct }\end{array}$ & Items & Loadings & AVE & $\mathbf{C R}$ \\
\hline $\begin{array}{l}\text { Distributive } \\
\text { Justice }\end{array}$ & $\begin{array}{l}\text { DJ1 } \\
\text { DJ2 } \\
\text { DJ3 } \\
\text { DJ4 }\end{array}$ & $\begin{array}{l}0.7 \\
0.9 \\
0.7 \\
0.9\end{array}$ & 0.8 & 0.8 \\
\hline $\begin{array}{l}\text { Procedural } \\
\text { Justice }\end{array}$ & $\begin{array}{l}\text { PJ1 } \\
\text { PJ2 } \\
\text { PJ3 } \\
\text { PJ4 } \\
\text { PJ5 } \\
\text { PJ6 }\end{array}$ & $\begin{array}{l}0.7 \\
0.7 \\
0.8 \\
0.8 \\
0.8 \\
0.7 \\
\end{array}$ & 0.7 & 0.8 \\
\hline $\begin{array}{l}\text { Integrating } \\
\text { Style }\end{array}$ & $\begin{array}{l}\text { INT1 } \\
\text { INT2 } \\
\text { INT3 } \\
\text { INT4 } \\
\text { INT5 } \\
\text { INT6 } \\
\text { INT7 }\end{array}$ & $\begin{array}{l}0.8 \\
0.7 \\
0.8 \\
0.8 \\
0.9 \\
0.8 \\
0.9\end{array}$ & 0.8 & 0.8 \\
\hline $\begin{array}{l}\text { Compromising } \\
\text { Style }\end{array}$ & $\begin{array}{l}\text { COM1 } \\
\text { COM2 } \\
\text { COM3 } \\
\text { COM4 }\end{array}$ & $\begin{array}{l}0.7 \\
0.6 \\
0.8 \\
0.7\end{array}$ & 0.8 & 0.9 \\
\hline Avoiding Style & $\begin{array}{l}\text { AVO1 } \\
\text { AVO2 } \\
\text { AVO3 } \\
\text { AVO4 } \\
\text { AVO5 }\end{array}$ & $\begin{array}{l}0.6 \\
0.6 \\
0.6 \\
0.5 \\
0.6 \\
\end{array}$ & 0.7 & 0.7 \\
\hline $\begin{array}{l}\text { Affective } \\
\text { Commitment }\end{array}$ & $\begin{array}{l}\text { AC1 } \\
\text { AC3 } \\
\text { AC4 } \\
\text { AC5 } \\
\text { AC6 }\end{array}$ & $\begin{array}{l}0.8 \\
0.8 \\
0.9 \\
0.8 \\
0.8\end{array}$ & 0.7 & 0.9 \\
\hline
\end{tabular}


Then, the correlations between the measures are compared with the square root of the AVEs in order to assess the discriminant validity. Table 5 exhibits all of the correlations between the measures were smaller than the square root of thee shown on the diagonals.

Therefore, the items measuring the constructs discriminant validity for this study are satisfactory. Finally, reliability was also accessed via Cronbach's alpha coefficient, which should have a value higher than the recommended value of 0.60 as indicated by Nunally and Berstein (1994). In addition, all of the constructs have alpha values of above the recommended value and therefore, the measures are reliable (see Table 5).

Table 5. Discriminant Validity of Construct

\begin{tabular}{|l|l|l|l|l|l|l|}
\hline & AC & AV & CO & DJ & IN & PJ \\
\hline AC & $\mathbf{0 . 8}$ & & & & & \\
\hline AV & -0.3 & $\mathbf{0 . 8}$ & & & & \\
\hline CO & 0.5 & -0.3 & $\mathbf{0 . 9}$ & & & \\
\hline DJ & 0.6 & -0.2 & 0.5 & $\mathbf{0 . 9}$ & & \\
\hline IN & 0.5 & -0.3 & 0.6 & 0.4 & $\mathbf{0 . 9}$ & \\
\hline PJ & 0.5 & -0.2 & 0.5 & 0.7 & 0.6 & $\mathbf{0 . 8}$ \\
\hline
\end{tabular}

Note: The bolded diagonals represent square root of the AVE while the off-diagonals represent the correlation.

\subsection{Hypotheses Testing}

The hypotheses in this study were tested using path analysis. The $R^{2}$ value for integrating, compromising, and avoiding style were 0.463 , $0.419,0.092$ meaning that $46.3 \%, 41.9 \%$, and $9.2 \%$ of the variance in conflict management styles are explained by distributive and procedural justice respectively. Looking at each predictors individually, distributive justice was a positive significant predictor for integrating style $(\beta=0.432$, $p<0.01)$ and compromising style $(\beta=0.178, p<$ 0.01 ) but negative significant predictor for avoiding style $(\beta=-0.263, p<0.01)$. Additionally, procedural justice was also found to be a positive significant predictor for integrating style $(\beta=0.372, p<0.01)$, compromising style $(\beta=0.271, p<0.01)$ but negative significant predictor for avoiding style $(\beta=$ $-0.262, p<0.01$ ). Therefore, H1 was supported (see Table 6).

With affective commitment as the dependent variable, the $R 2$ value revealed that $45 \%$, of the variance for affective commitment was explained by integrating, obliging, compromising, dominating and avoiding style. Integrating style $(\beta=$ $0.293, p<0.01)$, obliging style $(\beta=0.217, p<0.01)$ and compromising style $(\beta=0.174, p<0.01)$ were found positively significant with affective commitment while avoiding style $(\beta=-0.197, p<$ 0.01 ) was negatively significant with affective commitment. Therefore, H2 was supported (see Table 7).

Table 6. Coefficient beta and $r^{2}$ for conflict management styles

\begin{tabular}{|l|l|l|l|l|}
\hline Hypothes & Relationship & Coefficie & $\mathbf{R}^{2}$ & Comme \\
\hline
\end{tabular}

\begin{tabular}{|c|c|c|c|c|}
\hline es & & nt $(\beta)$ & & nt \\
\hline 1.1 & $\begin{array}{l}\text { Distributive } \\
\text { Justice } \\
\rightarrow \text { Integrating } \\
\text { Style }\end{array}$ & $0.4 * * *$ & \multirow[t]{2}{*}{0.4} & $\begin{array}{l}\text { Support } \\
\text { ed }\end{array}$ \\
\hline 1.2 & $\begin{array}{l}\text { Procedural } \\
\text { Justice } \\
\rightarrow \text { Integrating } \\
\text { Style }\end{array}$ & $0.3 * * *$ & & $\begin{array}{l}\text { Support } \\
\text { ed }\end{array}$ \\
\hline 1.3 & $\begin{array}{l}\text { Distributive } \\
\text { Justice } \\
\rightarrow \text { Compromis } \\
\text { ing Style }\end{array}$ & $0.1^{* *}$ & \multirow[t]{2}{*}{0.4} & $\begin{array}{l}\text { Support } \\
\text { ed }\end{array}$ \\
\hline 1.4 & $\begin{array}{l}\text { Procedural } \\
\text { Justice } \\
\rightarrow \text { Compromis } \\
\text { ing Style }\end{array}$ & $0.2 * * *$ & & $\begin{array}{l}\text { Support } \\
\text { ed }\end{array}$ \\
\hline 1.5 & $\begin{array}{l}\text { Distributive } \\
\text { Justice } \\
\rightarrow \text { Avoiding } \\
\text { Style }\end{array}$ & $-0.2 * * *$ & \multirow[t]{2}{*}{$\begin{array}{l}0.0 \\
9\end{array}$} & $\begin{array}{l}\text { Support } \\
\text { ed }\end{array}$ \\
\hline 1.6 & $\begin{array}{l}\text { Procedural } \\
\text { Justice } \\
\rightarrow \text { Avoiding } \\
\text { Style }\end{array}$ & $-0.2 * * *$ & & $\begin{array}{l}\text { Support } \\
\text { ed }\end{array}$ \\
\hline
\end{tabular}

Table 7. Coefficient Beta and $\mathrm{R}^{2}$ for Affective Commitment

\begin{tabular}{|c|c|c|c|c|}
\hline $\begin{array}{l}\text { Hypothe } \\
\text { ses }\end{array}$ & $\begin{array}{l}\text { Relationsh } \\
\text { ip }\end{array}$ & $\begin{array}{l}\text { Coeffici } \\
\text { ent }(\beta)\end{array}$ & $\mathbf{R}^{2}$ & $\begin{array}{l}\text { Comm } \\
\text { ent }\end{array}$ \\
\hline 2.1 & $\begin{array}{l}\text { Integrating } \\
\text { Style } \\
\rightarrow \text { Affectiv } \\
\text { e } \\
\text { Commitme } \\
\text { nt }\end{array}$ & $\begin{array}{l}0.293 * * \\
*\end{array}$ & \multirow[t]{3}{*}{$\begin{array}{l}0.4 \\
5\end{array}$} & $\begin{array}{l}\text { Support } \\
\text { ed }\end{array}$ \\
\hline 2.2 & $\begin{array}{l}\text { Compromis } \\
\text { ing Style } \\
\rightarrow \text { Affectiv } \\
\text { e } \\
\text { Commitme } \\
\text { nt }\end{array}$ & $0.174 * *$ & & $\begin{array}{l}\text { Support } \\
\text { ed }\end{array}$ \\
\hline 2.3 & $\begin{array}{l}\text { Avoiding } \\
\text { Style } \\
\rightarrow \text { Affectiv } \\
\text { e } \\
\text { Commitme } \\
\text { nt }\end{array}$ & $-0.197 * *$ & & $\begin{array}{l}\text { Rejecte } \\
\text { d }\end{array}$ \\
\hline
\end{tabular}

Next, to determine the mediating effect of conflict management styles between distributive and procedural justice and affective commitment, bootstrapping of 303 samples was conducted. After bootstrapping, both paths from distributive and procedural justice have significant impacts on affective commitment via integrating, compromising and avoiding style (see Table 8). Therefore, H3 also was supported.

Table 8. Mediating effects 


\begin{tabular}{|c|c|c|c|c|c|}
\hline H & Relationship & $\begin{array}{c}\text { Path A } \\
(\boldsymbol{\beta})\end{array}$ & $\begin{array}{c}\text { Path B } \\
(\boldsymbol{\beta})\end{array}$ & $\begin{array}{c}\text { t-value } \\
\text { (After } \\
\text { Bootstrap) }\end{array}$ & $\begin{array}{c}\text { Mediating } \\
\text { Effect }\end{array}$ \\
\hline $\mathrm{H} 3.1$ & $\mathrm{DJ} \rightarrow \mathrm{IN} \rightarrow \mathrm{AC}$ & $0.4^{* * *}$ & $0.2^{* * *}$ & $5.7^{* * *}$ & Yes \\
\hline $\mathrm{H} 3.2$ & $\mathrm{PJ} \rightarrow \mathrm{IN} \rightarrow \mathrm{AC}$ & $0.3^{* * *}$ & $0.2^{* * *}$ & $3.5^{* * *}$ & Yes \\
\hline $\mathrm{H} 3.3$ & $\mathrm{DJ} \rightarrow \mathrm{CO} \rightarrow \mathrm{AC}$ & $0.1^{* *}$ & $0.1^{* *}$ & $2.3^{* * *}$ & Yes \\
\hline $\mathrm{H} 3.4$ & $\mathrm{PJ} \rightarrow \mathrm{CO} \rightarrow \mathrm{AC}$ & $0.2^{* * *}$ & $0.1^{* *}$ & $2.5^{* * *}$ & Yes \\
\hline H3.5 & DJ $\rightarrow \mathrm{AV} \rightarrow \mathrm{AC}$ & $-0.2^{* * *}$ & $-0.1^{* *}$ & 1.7 & Yes \\
\hline $\mathrm{H} 3.6$ & PJ $\rightarrow \mathrm{AV} \rightarrow \mathrm{AC}$ & $-0.2^{* * *}$ & $-0.1^{* *}$ & 1.7 & Yes \\
\hline
\end{tabular}

\subsection{Discussion}

The present study discovered that both distributive and procedural justice have significant positive relationship with integrating, and compromising; and negative significant relationship with avoiding style consistent with prior studies such as Rahim et al. (2001) and Tatum and Eberlin (2008). This means that when employees observe that their organization distributes rewards fairly in terms of monetary benefits, career promotions, performance evaluation and they were treated with respect, they respond to their subordinates by supporting them in order to help the organization achieve its objective, and vice versa for avoiding style.

The result of this study also proved that integrating and compromising styles were positively significant with affective commitment while avoiding style was discovered to be related negatively and significantly to affective commitment. These findings reflected the results of previous empirical studies (e.g. Ahmad \& Marinah, 2013; Ndubisi, 2011; Griffin et al., 2010; London \& Howat, 1978). Thus proving that when employees perceive that the use of integrating,obliging or compromising styles is apparent in the organisation, it will reduce the likelihood of negative attitude and behaviours and generate a stronger sense of commitment to the organization. On the other hand, employees who utilize the avoiding style tend to exhibit discontentment, discourtesy, intention to quit and extremely dissatisfied with organisation.

The result of this study discovered that the integrating, compromising and avoiding style mediated between distributive and procedural justice and affective commitment. The results are consistent with the findings from Fisher et al. (2005) where conflict management styles (integrating style, compromising style and avoiding style) are the combinations that contribute to the prevention of conflict among employees in the organization.

\subsection{Theoretical Implications}

One of the contributions of the present study is in proving the mediating effect of conflict management styles between organizational justice and organizational commitment. As indicated by Ahmad et al. (2013), the research on conflict management as a mediator is scarce but it is an important management tool in stabilising the organization as it is a highly visible phenomenon to the employees.
Likewise, the examination of the impact of distributive and procedural justice on integrating, compromising and avoiding styles and its indirect effect on affective commitment discovered that conflict management styles is critical issue in influencing organizational outcomes.

\subsection{Practical Implications}

A major contribution of this present study proves that integrating, compromising and avoiding styles are an effective management tool which can be utilized in the academic organization. It could act as a guideline in resolving organizational justice issues among the academic staffs. Understanding conflict management styles can help the academic staffs to recognize and evaluate situations that could lead to conflict. By having the ability to monitor and assess difficult situations, the academic staffs will be able to prepare coping strategy in anticipating such conflicts in organizations.

\subsection{CONCLUSION}

Overall, it could be concluded that the findings had achieved the objectives of this study. The academic staffs perceived integrating, compromising and avoiding styles to be present in their respective organization, thus, motivating them to be more committed to their organization. In addition, academic staffs who perceived integrating and compromising styles being practiced in their organizations have higher value-effort of affective commitment towards their organization. To maintain and ensure the professionalism and quality of conflict management within the organizations and among the staffs, it is recommended that the staffs' interpersonal skill and knowledge must be continuously developed in managing conflict. It can be implemented by improving the staffs' understanding on the strength and weaknesses of the styles of managing conflict and how to implement it at the right place and the right time. As a result, turnover which is the problem among the academic staffs can be overcome.

\section{REFERENCES}

1. Ahmad, A. R., \& Marinah, A. (2013). Learning organization and organizational commitment in primary school. International Proceedings of Economics Development and Research, 60 (12).

2. Ahmad, Z.M.S., Jamilah, O. \& Jeffrey, L.D. 2013. The Effects of Perceived Leadership Styles and Organizational Citizenship Behavior

* Corresponding author: muhammadasyraf@unimap.edu.my 
on Employee Engagement: The Mediating Role of Conflict Management. International Journal of Business and Management, 8(8), 91-99.

3. Aizat, A. R., Nizam, S. S., Zaifudin, S. Z., \& Turiman, S. (2014). Turnover intention among academics: A case study of private higher learning education in Klang Valley. Pertanika J. Soc. Sci. \& Hum. 22 (1), 321 - 334.

4. Alzahrani, M. (2013). A comparative study of the relationships between conflict management styles and job satisfaction, organizational commitment, and propensity to leave the job among Saudi and American Universities' faculty members. Published PhD Diss., Florida Atlantic University.

5. Azman, I., Amy, Y., Elizabeth, Y., Kong, L.-K., \& Ju, S. Y. (2010). Occupational stress features, emotional intelligence and job satisfaction: An empirical study in private institutions of higher learning. Negotium, 16(5), 5-33.

6. Bahramzadeh, H., \& Yadegari, M. (2010). Analysis of the relationship between organizational justice and organizational commitment of employees of girls' schools in the different regions of Mashhad Education Departments. Tommorow's Management Quarterly, 21, 55-65.

7. Choong, Y. O., Keh, C. G., Tan, Y. T., \& Tan, C. E. (2013). Impacts of demographic antecedents toward turnover intention amongst academic staff in Malaysian private universities. Australian Journal of Basic and Applied Sciences, 7(6), 46-54.

8. Colquitt, J. A. (2001). On the dimensionality of organizational justice: a construct validation of a measure. Journal of Applied Psychology, 86(3), 386 - 400.

9. Elamin, A. M. (2012). Perceived organizational justice and work-related attitudes: A study of Saudi employees. World Journal of Entrepreneurship, Management and Sustainable Development, 8(1), 71-88.

10. Fisher, S. G., Macrosson, W. D., \& Semple, J. H. (2005). Control and belbin's team roles. Personnel Review, 30, 578-588.

11. Greenberg, J. \& Baron, R. A. (2003). Behavior in organization: Understanding and managing the human side of work. 8th edition. New Jersey: Prentice Hall.

12. Griffin, D., \& Steen, S. (2011). A social justice approach to school counselling. Journal for Social Action in Counseling and Psychology, 3(1), 74-85.

13. Hair, J. F., Ringle, C. M., \& Sarstedt, M. (2013). Partial least squares structural equation modeling: Rigorous applications, better results and higher acceptance. Long Range Planning, $46(1), 1-12$.

14. Khan, S. K., \& Rashid, M. Z. A. (2012). The mediating effect of organizational commitment in the organizational culture, leadership and organizational justice relationship with organizational citizenship behavior: A study of academician in private higher learning institutions in Malaysia. International Journal of Business and Social Science, 3, 83-91.

15. Lemons, M. A., \& Jones, C. A. (2001). Procedural justice in promotion decisions: Using perceptions of fairness to build employee commitment. Journal of Managerial Psychology, 16(4), 268 - 281.

16. London, M., \& Howat, G. (1978). Relationship between employee commitment and conflict resolution behavior. Journal of Vocational Behavior, 13, 1-14.

17. Meyer J. P., Allen, N. J., \& Smith, C. (1993). Commitment to organizations and occupations: Extension and test of a three-component conceptualization. Journal of Applied Psychology, 78, 538-551.

18. Ndubisi, N. O. (2011). Conflict handling, trust and commitment in outsourcing relationship: A Chinese and Indian study. Science Direct Journal, 40(1), 109- 117.

19. Nunnally, J. C., \& Bernstein, I. H. (1994). Psychometric theory. 3rd edition. New York: McGraw-Hill.

20. Preacher, K. J., \& Hayes A. F. (2008). Asymptotic and resampling strategies for assessing and comparing indirect effects in multiple mediator models. Behavior Research Methods, 40(3), 879-891.

21. Rahim, M. A. (1983). A measure of styles of handling interpersonal conflict. Academy of Management Journal, 26, 368- 376.

22. Rahim, M. A. (2002). Toward a theory of managing organizational conflict. International Journal of Conflict Management, 13(3), 206235.

23. Rahim, M. A. (2010). Managing Conflict in Organizations (4th Ed.). Transaction Publishers. New York.

24. Rahim, M. A., Magner, N. R., \& Shapiro, D. L. (2000). Do justice perception influence styles of handling conflict with supervisors? What justice perceptions, precisely? International Journal of Conflict Management, 11(1), 9-31.

25. Schlaerth, A., Ensari, N., \& Christian, J. (2013). A meta-analytical review of the relationship between emotional intelligence and leaders' constructive conflict management. Group Processes \& Intergroup Relations, 16(1), 126136.

26. Seto, D. M. (2013). Breach of psychological contract and workplace outcomes: The mediational role of job satisfaction, organizational commitment, and employee engagement. Published PhD Diss., Alliant International University.

27. Seyed, J. S. R., Faraahi, M. M., \& Taheri, A. G. H. (2009). How different dimensions of organizational justice affect the different dimensions of job and organizational 
satisfaction. Journal of Business Management, 1, 55-70.

28. Sofiah, K. K., Zabid, M. A. R., \& Lionel, K. V. (2016). The role of organisation commitment in enhancing organisation citizenship behaviour: A study of academics in Malaysian private universities. Int. Journal of Economics and Management, 10(2), 221 - 239.

29. Suliman, A., \& Kathairi, M. (2013). Organizational justice, commitment and performance in developing countries: The case of the UAE. Employee Relations, 35(1), 98-115.

30. Tatum, B. C., \& Eberlin, R. J. (2008). The relationship between organizational justice and conflict style. Business Strategy Series, 9(6): 297-305.

31. Tyler, T. R., \& Lind, E. A. (1992). A relational model of authority in groups. Advances in Experimental Social Psychology, 25, 115 - 191.

32. Varman, R., \& Bhatnagar, D. (1999). Power and politics in grievance resolution: Managing meaning of due process in an organization. Human Relations, 52 (3), 349-380.

33. Zayas-Ortiz, M., Ernesto Rosario, E., Marquez, E., \& Gruñeiro, P. C. (2015). Relationship between organizational commitments and organizational citizenship behaviour in a sample of private banking employees. International Journal of Sociology and Social Policy, 35(1/2), 91-106.

34. Zulkiflee, D., Faizal, M. M. I., Shakizah, W. W. M. N. (2012). The relationship between procedural justice and grievance handling styles. International Conference on Management, Economics and Finance (ICMEF 2012) Proceeding. 